Article

\title{
Structural Elucidation of a Novel Lipooligosaccharide from the Cold-Adapted Bacterium OMVs Producer Shewanella sp. HM13
}

\author{
Angela Casillo ${ }^{1, *}$, Rossella Di Guida ${ }^{1}$, Sara Carillo ${ }^{2}$, Chen Chen ${ }^{3}$, Kouhei Kamasaka ${ }^{3}$, \\ Jun Kawamoto ${ }^{3}$, Tatsuo Kurihara ${ }^{3}$ and Maria Michela Corsaro ${ }^{1, *(D)}$ \\ 1 Department of Chemical Sciences, University of Naples “Federico II", Complesso Universitario Monte S. \\ Angelo, Via Cintia 4, 80126 Naples, Italy; ross.diguida@gmail.com \\ 2 Characterisation and Comparability Laboratory, National Institute for Bioprocessing Research and Training. \\ Fosters Avenue, Mount Merrion. Blackrock, Co., A94 X099 Dublin, Ireland; sara.carillo@nibrt.ie \\ 3 Institute for Chemical Research, Kyoto University, Uji, Kyoto 611-0011, Japan; \\ chenchen@mbc.kuicr.kyoto-u.ac.jp (C.C.); kama.kinoko144@mbc.kuicr.kyoto-u.ac.jp (K.K.); \\ jun_k@mbc.kuicr.kyoto-u.ac.jp (J.K.); kurihara@scl.kyoto-u.ac.jp (T.K.) \\ * Correspondence: angela.casillo@unina.it (A.C.); corsaro@unina.it (M.M.C.); Tel.: +39-081-674149 (M.M.C.)
}

Received: 11 December 2018; Accepted: 3 January 2019; Published: 8 January 2019

\begin{abstract}
Shewanella sp. HM13 is a cold-adapted Gram-negative bacterium isolated from the intestine of a horse mackerel. It produces a large amount of outer membrane vesicles (OMVs), which are particles released in the medium where the bacterium is cultured. This strain biosynthesizes a single major cargo protein in the OMVs, a fact that makes Shewanella sp. HM13 a good candidate for the production of extracellular recombinant proteins. Therefore, the structural characterization of the components of the vesicles, such as lipopolysaccharides, takes on a fundamental role for understanding the mechanism of biogenesis of the OMVs and their applications. The aim of this study was to investigate the structure of the oligosaccharide (OS) isolated from Shewanella sp. HM13 cells as the first step for a comparison with that from the vesicles. The lipooligosaccharide (LOS) was isolated from dry cells, purified, and hydrolyzed by alkaline treatment. The obtained OS was analyzed completely, and the composition of fatty acids was obtained by chemical methods. In particular, the OS was investigated in detail by ${ }^{1} \mathrm{H}$ and ${ }^{13} \mathrm{C}$ NMR spectroscopy and MALDI-TOF mass spectrometry. The oligosaccharide was characterized by the presence of a residue of 8-amino-3,8-dideoxy-manno-oct-2-ulosonic acid (Kdo8N) and of a D,D-heptose, with both residues being identified in other oligosaccharides from Shewanella species.
\end{abstract}

Keywords: psychrophile; lipooligosaccharide (LOS); structure elucidation; NMR spectroscopy; outer membrane vesicles (OMVs); MALDI-TOF mass spectrometry; cold adaptation

\section{Introduction}

Cold-adapted bacteria are extremophiles that are able to thrive in permanently cold environments. Some of these habitats are exposed to temperatures below $5{ }^{\circ} \mathrm{C}[1]$, and for this reason cold-adapted microorganisms have developed unique physiological tools to survive in these harsh conditions. Cold habitats are also considered as surprising reservoirs of biotechnological molecules such as antibiofilm molecules [2], surfactants [3], cold-active enzymes [4], antifreeze proteins, glycoproteins, and polysaccharides [5-7]. Many psychrophiles have been reported to produce outer membrane vesicles (OMVs) [8]. It has been reported that the OMVs produced by a cold-adapted bacterium contain putative proteolytic enzymes, which can serve to degrade high molecular weight molecules present in the surrounding cells $[9,10]$ helping the bacterium in the survival of such harsh conditions. 
OMVs are small spherical particles commonly secreted from Gram-negative bacteria, and their role is not yet fully understood [11,12]. They are derived from the outer membrane (OM) by sticking out a portion of the envelope, and, for this reason, they usually contain phospholipids, outer membrane and periplasmic proteins, and lipopolysaccharides (LPSs). The latter molecules are the main components of Gram-negative bacterial OMs, for which they account for approximately $75 \%$ of the surface. LPSs are amphiphilic molecules with a conserved structure [13] fundamental for the viability and survival of Gram-negative bacteria and cyanobacteria [14-16], since they significantly affect the cell homeostasis due to their influence in cellular integrity and OM permeability [17].

Although LPS is also considered to be a major component of OMVs, very little is known about the LPS structure belonging to OMVs, which deeply limits the knowledge about their role in OMVs. This is mainly because the isolation and characterization of LPS from OMVs is usually impaired by the low amount of produced material. Thus, it is important to use a bacterial strain that abundantly produces OMVs to overcome this problem. Characterization of the structure of the LPS isolated from the bacterial cells, followed by a comparison with the LPS isolated from the OMVs, would greatly contribute to our understanding of the role of LPS in OMVs. Moreover, LPS structural characterization allows us to deepen the knowledge of psychrophilic marine Gram-negative bacteria and their mechanisms of adaptation to these prohibitive environments.

Herein, we describe the structural characterization of the carbohydrate backbone of the lipooligosaccharide (LOS) isolated from Shewanella sp. HM13, a cold-adapted Gram-negative bacterial strain that was isolated from the intestine of a horse mackerel and was found to produce a large amount of OMVs [18]. The OMVs produced by this strain carry a single major cargo protein named P49. This high relative abundance of a single cargo molecule in OMVs is a unique characteristic of this strain. The strain is thus expected to be useful as a host for extracellular production of recombinant proteins, including membrane proteins, as cargoes of OMVs by using the OMV-targeting mechanism of P49. Structural characterization of the molecules constituting the outer membrane of this strain is important for understanding of the mechanism of biogenesis of OMVs and their applications.

The fatty acids were removed from the lipooligosaccharide by mild hydrazinolysis (O-deacylation), followed by an alkaline treatment with $4 \mathrm{M} \mathrm{KOH} \mathrm{(} \mathrm{N}$-deacylation). The obtained product was investigated by mono- and two-dimensional NMR spectroscopy, MALDI-TOF mass spectrometry, and chemical analysis.

\section{Results and Discussion}

\subsection{LOS Extraction and Purification}

Shewanella sp. HM13 cells were grown in Luria Bertani (LB) medium at $4{ }^{\circ} \mathrm{C}$, as described in the Experimental section, and the LPS was isolated from dried cells using the phenol/chloroform/light petroleum (PCP) method [19], with a yield of 2.4\%. As illustrated in Figure 1, sodium deoxycholatepolyacrylamide gel electrophoresis analysis (DOC-PAGE) showed, after silver nitrate gel staining, a fast migrating species typical of rough LPS (e.g., LOS). The cellular debris were also extracted by the phenol/water method [20], obtaining the same fast-migrating DOC-PAGE LOS together with proteins and nucleic acids (data not shown).

The compositional monosaccharides analysis of the obtained LOS revealed the presence of D-glucose (D-Glc), 2-amino-2-deoxy-D-glucose (D-GlcN), L-glycero-D-manno-heptose (L,D-Hep), and D-glycero-D-manno-heptose (D,D-Hep). Methylation analysis indicated the presence of terminal glucose, 2-substituted glucose, 2-substituted heptose, terminal heptose, and 2,6,7-trisubstituted heptose. 


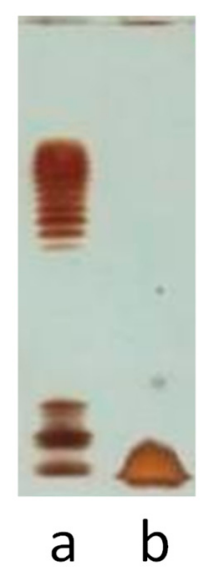

Figure 1. Analysis of the lipooligosaccharide (LOS) (Lane b) fraction from Shewanella sp. HM13 by $14 \%$ deoxycholate-polyacrylamide gel electrophoresis analysis (DOC-PAGE). The gel was stained with silver nitrate and the LOS was compared with the lipopolysaccharide (LPS) from Escherichia coli O127: B8 (Lane a).

In addition, gas chromatography-mass spectrometry (GC-MS) analysis of fatty acid methyl esters showed the presence of $\mathrm{C} 12: 0(3 \mathrm{OH}), \mathrm{C} 13: 0(3 \mathrm{OH}), \mathrm{C} 14: 0(3 \mathrm{OH}), \mathrm{C} 12: 0, \mathrm{C} 13: 0, \mathrm{C} 14: 0$, and $\mathrm{C} 15: 0$ as the major components.

\subsection{LOS Deacylation}

Alkaline degradation by mild hydrazinolysis of the LOS afforded an O-deacylated LOS, named LOS-OH, which was analyzed by negative ions MALDI-TOF (Figure 2). The spectrum revealed the presence of a cluster of ions, attributable to the LOS-OH molecule. At higher molecular masses, the signal at $m / z 2298.6$ was assigned the following composition: $\mathrm{Hex}_{3} \mathrm{Hep}_{3} \mathrm{Kdo} 8 \mathrm{NGlcN}_{2} \mathrm{P}_{3}$ $[\mathrm{C} 13: 0(3 \mathrm{OH})][\mathrm{C} 14: 0(3 \mathrm{OH})]\left(\right.$ Calculated $\left.[\mathrm{M}-\mathrm{H}]^{-}=2298.84 \mathrm{Da}\right)$, thus suggesting the presence of a residue of 8-amino-3,8-dideoxy-manno-oct-2-ulosonic acid (Kdo8N). The appearance of the Kdo8N monosaccharide was not surprising, since it has often been reported for Shewanella LPSs [21-24]. Differences of \pm 14 Da with respect to the main signal at $m / z 2298.6$ are attributable to the different lengths of fatty acids substituting the GlcN residues. A less intense signal was observed at $m / z 2422.6$, suggesting the presence of an additional phosphoethanolamine. Moreover, signals attributable to a core oligosaccharide and a lipid A, arising from an in-source $\beta$-elimination at the glycosidic bond between the Kdo8N and the lipid A, were also displayed [25]. The signals at $m / z 1360.8$ and 1483.9 were both attributed to the core fragments, with the difference of 123 Da being due to the additional phosphoethanolamine. The signals of the decarboxylated core fragments were clearly visible at $m / z 1316.8$ and 1439.9 [25]. Finally, further fragmentation with losses of $18 \mathrm{u}$ could explain the signals at $m / z 1298.8$ and 1421.8. The LPS-OH was de- $N$-acylated by strong alkaline hydrolysis, and the obtained oligosaccharide, named OS, was submitted for full 2D NMR analysis. 

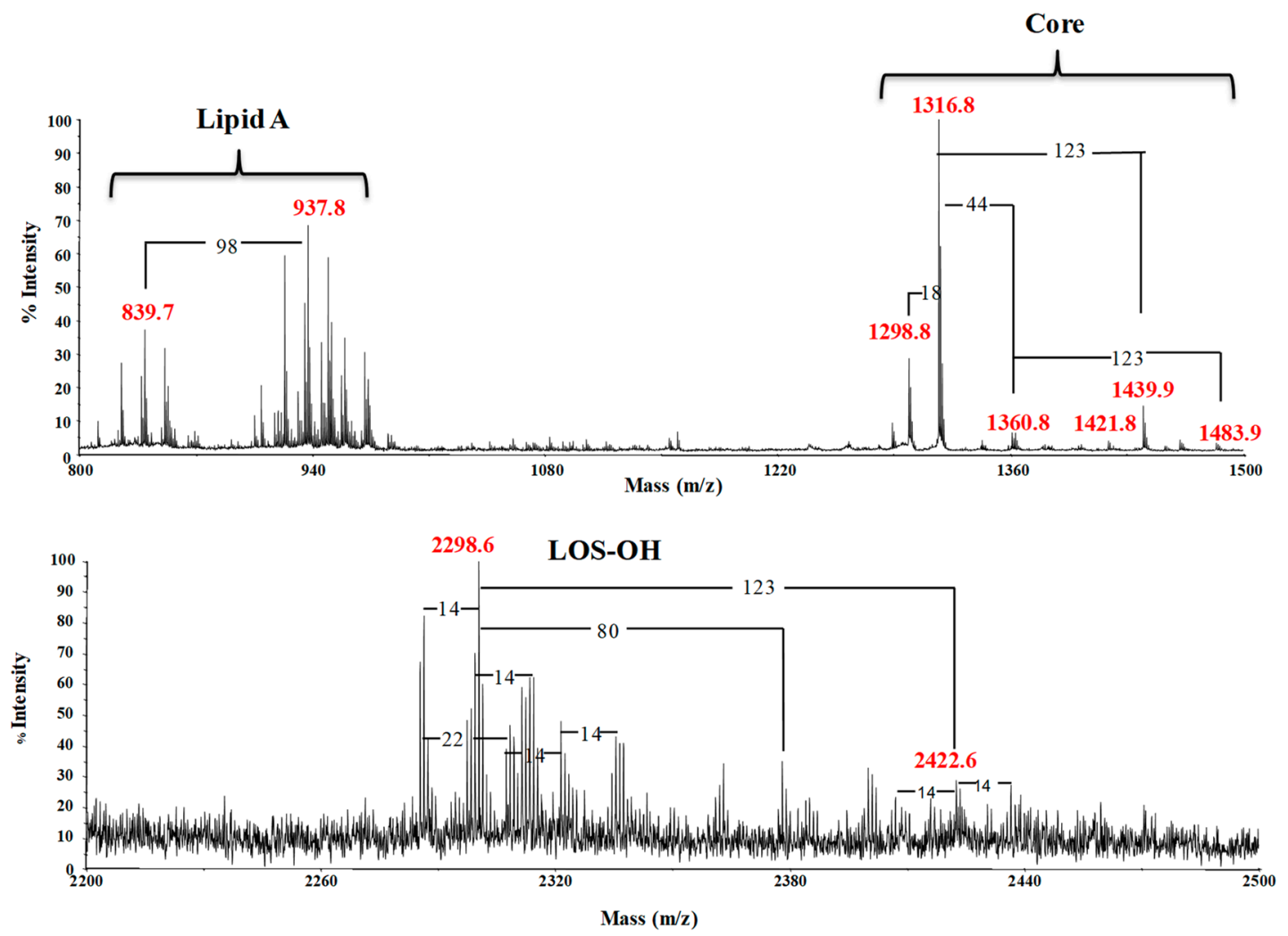

Figure 2. Negative ions MALDI-TOF mass spectrum recorded in reflectron mode of the $O$-deacylated LOS (LOS-OH). The upper spectrum displays the mass range 800-1500 m/z, whereas the lower one the mass range 2200-2500 m/z. Average masses are reported in the spectrum. The notation ' $14 \mathrm{Da}^{\prime}$ indicates differences of single $\mathrm{CH}_{2}$ in the fatty acid chains. ' $18 \mathrm{Da}^{\prime}$ indicates the loss of water. ' $44 \mathrm{Da}^{\prime}$ indicates the loss of $\mathrm{CO}_{2}$. ' $80 \mathrm{Da}^{\prime}$ indicates differences of phosphate groups. ' $98 \mathrm{Da}^{\prime}$ indicates the loss of phosphate plus water. ' $123 \mathrm{Da}^{\prime}$ indicates differences of phosphoethanolamine groups.

\subsection{NMR Spectroscopic Analysis of OS}

2D NMR spectroscopy $\left({ }^{1} \mathrm{H},{ }^{1} \mathrm{H}\right.$ double quantum filtered-correlation spectroscopy (DQF-COSY), ${ }^{1} \mathrm{H},{ }_{1}^{1} \mathrm{H}$ total correlation spectroscopy (TOCSY), ${ }^{1} \mathrm{H},{ }_{1}^{1} \mathrm{H}$ rotating frame Overhauser enhancement spectroscopy (ROESY), ${ }^{1} \mathrm{H},{ }^{13} \mathrm{C}$ distortionless enhancement by polarization transfer-heteronuclear single quantum coherence (DEPT-HSQC), and ${ }^{1} \mathrm{H}^{13} \mathrm{C}$ heteronuclear multiple bond correlation (HMBC) allowed for the assignment of all the proton and carbon chemical shifts of OS. The experiments indicated the pyranose rings for all the residues. Anomeric configurations were deduced by both proton and carbon anomeric chemical shifts, and by the ${ }^{1} J_{\mathrm{C} 1, \mathrm{H} 1}$ values obtained from the coupled ${ }^{1} \mathrm{H}$, ${ }^{13}$ C DEPT-HSQC experiment (Table 1). 
Table 1. ${ }^{1} \mathrm{H}$ and ${ }^{13} \mathrm{C}$ assignments of the oligosaccharide (OS) obtained from the LOS of Shewanella sp. HM13. All the values are referred to sodium 3-trimethylsilyl- $\left(2,2,3,3-{ }^{2} \mathrm{H}_{4}\right)$-propanoate (TSP, $\left.\delta_{\mathrm{H}} 0.00\right)$ and 1,4-dioxane in $\mathrm{D}_{2} \mathrm{O}\left(\delta_{\mathrm{C}} 67.40\right)$ as external standards. Spectra were recorded at $298 \mathrm{~K}$ at $600 \mathrm{MHz}$.

\begin{tabular}{|c|c|c|c|c|c|c|c|c|c|c|c|}
\hline Residue & $\begin{array}{c}\mathrm{H} 1 \\
\mathrm{C} 1 \\
{ }^{1} J_{\mathrm{C}, \mathrm{H}}\end{array}$ & $\begin{array}{l}\mathrm{H} 2 \\
\mathrm{C} 2\end{array}$ & $\begin{array}{l}\mathrm{H} 3 \\
\mathrm{C} 3\end{array}$ & $\begin{array}{l}\mathrm{H} 4 \\
\mathrm{C} 4\end{array}$ & $\begin{array}{l}\text { H5 } \\
\text { C5 }\end{array}$ & $\begin{array}{c}\text { H6a } \\
\text { C6 }\end{array}$ & H6b & $\begin{array}{c}\text { H7a } \\
\text { C7 }\end{array}$ & $\mathbf{H} 7 \mathrm{~b}$ & $\begin{array}{c}\text { H8a } \\
\text { C8 }\end{array}$ & H8b \\
\hline$\underset{\alpha-G l c N p 1 P}{\mathbf{A}}$ & $\begin{array}{l}5.65 \\
92.0 \\
179\end{array}$ & $\begin{array}{l}3.36 \\
55.8\end{array}$ & $\begin{array}{l}3.91 \\
71.2\end{array}$ & $\begin{array}{l}3.46 \\
71.4\end{array}$ & $\begin{array}{l}4.20 \\
73.5\end{array}$ & $\begin{array}{l}3.91 \\
70.9\end{array}$ & 4.32 & & & & \\
\hline$\underset{\alpha-t-G l c p}{\mathbf{B}}$ & $\begin{array}{l}5.40 \\
99.1 \\
182\end{array}$ & $\begin{array}{l}3.58 \\
72.5\end{array}$ & $\begin{array}{l}3.76 \\
74.0\end{array}$ & $\begin{array}{l}3.49 \\
70.7\end{array}$ & $\begin{array}{l}4.04 \\
73.5\end{array}$ & $\begin{array}{l}3.76 \\
61.9\end{array}$ & & & & & \\
\hline$\underset{\alpha-2-\mathrm{L}, \mathrm{D}-\mathrm{Hep} p}{\mathbf{C}}$ & $\begin{array}{l}5.37 \\
98.8 \\
184\end{array}$ & $\begin{array}{l}3.91 \\
82.1\end{array}$ & $\begin{array}{l}4.05 \\
71.7\end{array}$ & $\begin{array}{l}3.83 \\
68.7\end{array}$ & $\begin{array}{l}3.91 \\
75.2\end{array}$ & $\begin{array}{l}4.07 \\
70.3\end{array}$ & & $\begin{array}{l}3.78 \\
64.7\end{array}$ & 3.75 & & \\
\hline$\frac{\mathbf{D}}{\alpha-2,6,7-\mathrm{D}, \mathrm{D}-\mathrm{Hep} p}$ & $\begin{array}{c}5.17 \\
101.9 \\
170\end{array}$ & $\begin{array}{l}4.08 \\
79.4\end{array}$ & $\begin{array}{l}4.15 \\
71.7\end{array}$ & $\begin{array}{l}3.79 \\
68.7\end{array}$ & $\begin{array}{l}4.06 \\
74.4\end{array}$ & $\begin{array}{l}4.34 \\
78.2\end{array}$ & & $\begin{array}{l}4.02 \\
70.8\end{array}$ & 4.13 & & \\
\hline $\begin{array}{c}\mathbf{E} \\
\alpha-t-\mathrm{L}, \mathrm{D}-\mathrm{He} p\end{array}$ & $\begin{array}{c}5.12 \\
103.5 \\
173\end{array}$ & $\begin{array}{l}4.07 \\
70.5\end{array}$ & $\begin{array}{l}3.83 \\
72.0\end{array}$ & $\begin{array}{l}3.86 \\
67.6\end{array}$ & $\begin{array}{l}3.66 \\
73.8\end{array}$ & $\begin{array}{l}4.06 \\
70.5\end{array}$ & & $\begin{array}{l}3.84 \\
63.5\end{array}$ & 3.72 & & \\
\hline$\underset{\alpha-t-G l c p}{\mathbf{F}}$ & $\begin{array}{c}5.05 \\
102.3 \\
170 \\
\end{array}$ & $\begin{array}{l}3.59 \\
73.1\end{array}$ & $\begin{array}{l}3.72 \\
74.2\end{array}$ & $\begin{array}{l}3.49 \\
70.8\end{array}$ & $\begin{array}{l}4.04 \\
73.0\end{array}$ & $\begin{array}{l}3.81 \\
61.8\end{array}$ & & & & & \\
\hline$\underset{\beta-6-G l c N p 4 P}{\mathbf{G}}$ & $\begin{array}{c}4.95 \\
100.8 \\
164\end{array}$ & $\begin{array}{l}3.11 \\
56.9\end{array}$ & $\begin{array}{l}3.80 \\
73.6\end{array}$ & $\begin{array}{l}3.85 \\
74.5\end{array}$ & $\begin{array}{l}3.75 \\
75.4\end{array}$ & $\begin{array}{l}3.51 \\
63.4\end{array}$ & 3.73 & & & & \\
\hline$\underset{\beta-2-G l c p}{\mathbf{H}}$ & $\begin{array}{c}4.65 \\
105.0 \\
164\end{array}$ & $\begin{array}{l}3.47 \\
77.1\end{array}$ & $\begin{array}{l}3.57 \\
75.9\end{array}$ & $\begin{array}{l}3.42 \\
71.4\end{array}$ & $\begin{array}{l}3.44 \\
78.5\end{array}$ & $\begin{array}{l}3.73 \\
62.3\end{array}$ & 3.93 & & & & \\
\hline$\underset{\alpha-5-\mathrm{Kdo} 8 \mathrm{~N} p 4 P}{\mathbf{I}}$ & n.d. & 101.2 & $\begin{array}{l}2.01 \\
2.25 \\
35.8\end{array}$ & $\begin{array}{l}4.58 \\
71.3\end{array}$ & $\begin{array}{l}4.34 \\
76.3\end{array}$ & $\begin{array}{l}3.92 \\
74.6\end{array}$ & & $\begin{array}{l}4.02 \\
67.0\end{array}$ & & $\begin{array}{l}3.20 \\
44.4\end{array}$ & 3.50 \\
\hline
\end{tabular}

The ${ }^{1} \mathrm{H}$ NMR spectrum of $\mathrm{OS}$ displayed eight main anomeric signals, indicating at least the equivalent number of monosaccharides, as shown in Figure 3 (residues A-H). In addition, two proton signals, at $\delta 2.01$ and $2.25 \mathrm{ppm}$, confirmed the presence of a deoxy sugar (residue I). Starting from the chemical shift of $\mathrm{H} 1$ of residue $\mathbf{A}$, the spin system in the COSY and TOCSY spectra revealed a gluco configuration, since it showed the typical ${ }^{3} J_{\mathrm{H}, \mathrm{H}}$ vicinal coupling constant values. This residue was identified as the phosphorylated vicinal glucosamine residue ( $\alpha$-GlcNI), due to the multiplicity of its anomeric signal (doublet of doublets, ${ }^{3} J_{\mathrm{H} 1, \mathrm{H} 2}=3.6 \mathrm{~Hz}$ and ${ }^{3} J_{\mathrm{H} 1, \mathrm{P}}=7.0 \mathrm{~Hz}$ ) and the chemical shift of its C2 ( $855.8 \mathrm{ppm})$, as shown in Figure 4. Similarly, residue $\mathbf{G}$ was identified as the distal glucosamine ( $\beta$-GlcNII) of the lipid A backbone. The ROESY and HMBC experiments (see below) indicated that residues $\mathbf{G}$ and $\mathbf{A}$ were linked through a linkage $(1 \rightarrow 6)$. Residues $\mathbf{C}, \mathbf{D}$, and $\mathbf{E}$ were recognized to be $\alpha$-heptoses from their spin-system connectivities revealed in the COSY, TOCSY, and ROESY spectra. Indeed, in the TOCSY experiment, only the connectivities between $\mathrm{H} 1$ and $\mathrm{H} 2$ were clearly visible, indicating small values for the ${ }^{3} J_{\mathrm{H} 1, \mathrm{H} 2}$ and ${ }^{3} J_{\mathrm{H} 2, \mathrm{H} 3}$. Residue $\mathrm{C}$ was found to be 2-substituted, since the chemical shift of its C2 was shifted downfield to $82.1 \mathrm{ppm}$ (the reference value for an unsubstituted residue is $71.9 \mathrm{ppm}$ ) [26]. 


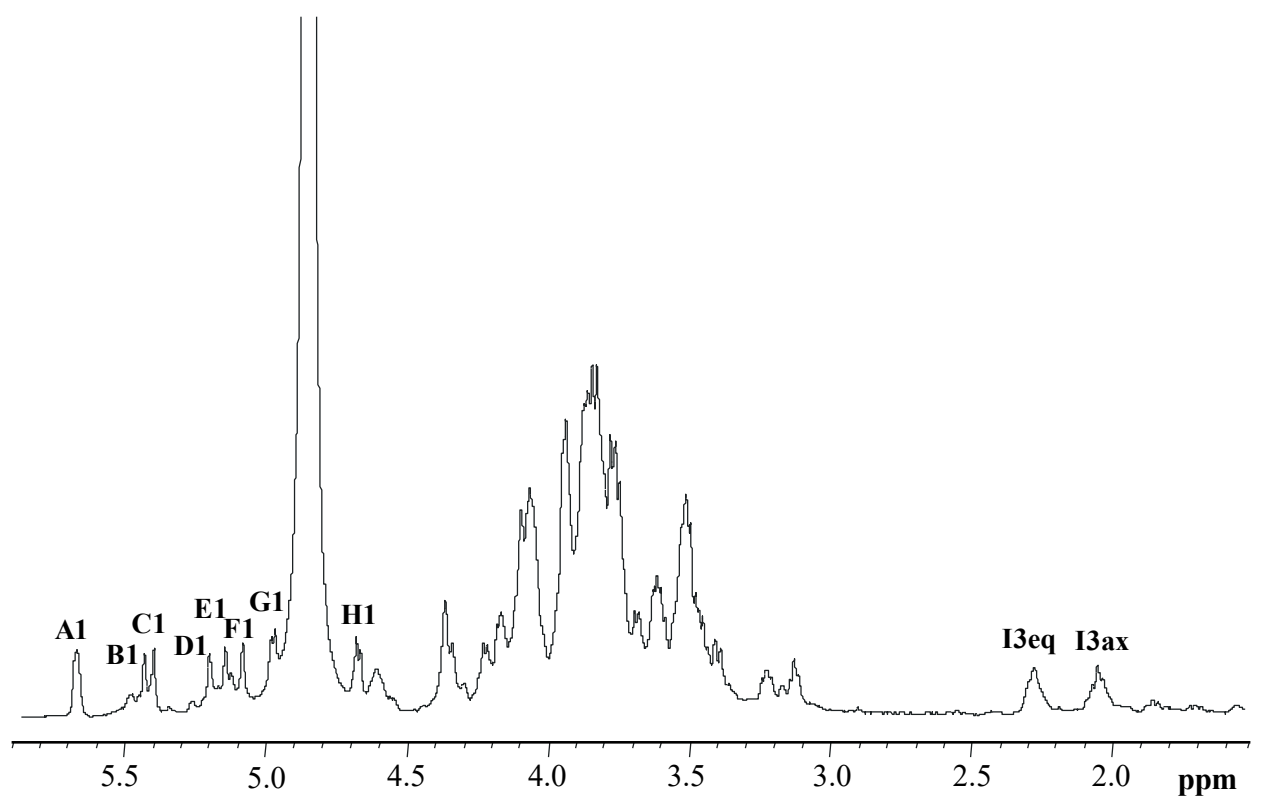

Figure 3. ${ }^{1} \mathrm{H}$ NMR spectrum of the oligosaccharide (OS) obtained by strong alkaline hydrolysis of the LOS isolated from Shewanella sp. HM13. The spectrum was recorded in $\mathrm{D}_{2} \mathrm{O}$ at $298 \mathrm{~K}$ at $600 \mathrm{MHz}$. The letters refer to the residues as described in Table 1.

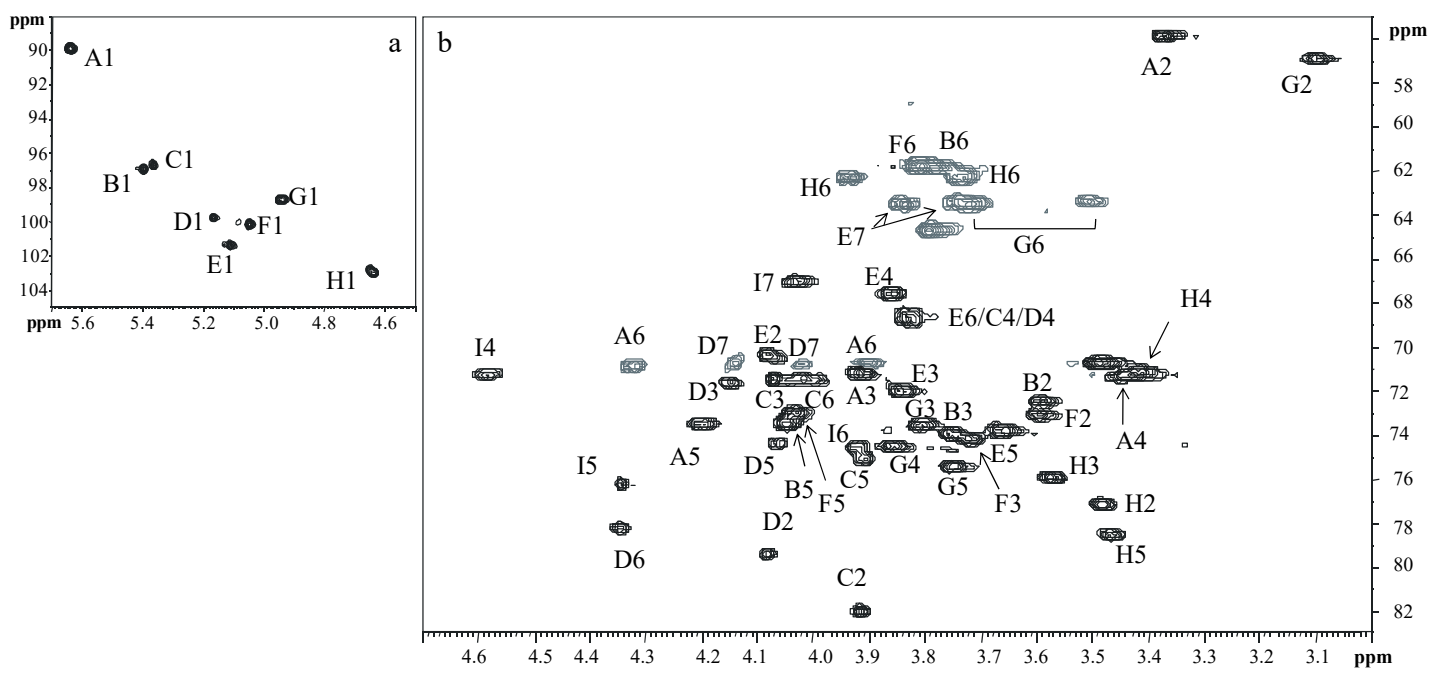

Figure 4. Anomeric (a) and carbinolic regions (b) of ${ }^{1} \mathrm{H}_{-}{ }^{13} \mathrm{C}$ DEPT-HSQC spectrum of OS of the LOS from Shewanella sp. HM13. The spectrum was recorded in $\mathrm{D}_{2} \mathrm{O}$ at $298 \mathrm{~K}$ at $600 \mathrm{MHz}$. The letters refer to the residues as described in Table 1.

Residue E did not show any downfield chemical shifts, and therefore was assigned to a terminal non-reducing $\alpha$-heptose. Spin system $\mathbf{C}$ was identified as a 2,6,7-trisubstituted heptose, since its $C 2, \mathrm{C} 6$, and C7 carbon chemical shifts occurred at 79.4, 78.2, and $70.8 \mathrm{ppm}$, respectively. The D,D-configuration for this residue was suggested based on the presence of this type of residue in other Shewanella LOSs, and from the strong similarities of the proton and carbon chemical shifts of this residue with those already reported [27]. The gluco configuration for the spin systems of residues $\mathbf{B}, \mathbf{F}$, and $\mathbf{H}$ was inferred from the typical ${ }^{3} J_{\mathrm{H}, \mathrm{H}}$ vicinal coupling constant values. By comparison with the ${ }^{13} \mathrm{C}$ chemical shifts of unsubstituted residues [28], only one low-field shifted signal was identified for the $\mathrm{C} 2$ of residue $\mathbf{H}$, indicating that $\mathbf{B}$ and $\mathbf{F}$ were terminal non-reducing residues. Finally, $\mathbf{I}$ was identified as a Kdo8N residue based on the characteristic diastereotopic proton signals at $\delta 2.01$ and $2.25 \mathrm{ppm}$, and from the high-field chemical shift of its $C 8$ signal at $\delta 44.8 \mathrm{ppm}$. The $\alpha$ configuration for this residue was inferred from the coupling constant values of ${ }^{3} J_{\mathrm{H} 7, \mathrm{H} 8 \mathrm{a}}(8 \mathrm{~Hz})$ and of ${ }^{3} J_{\mathrm{H} 7, \mathrm{H} 8 \mathrm{~b}}(3.2 \mathrm{~Hz})$ [29]. 
The ${ }^{1} \mathrm{H}^{31} \mathrm{P}$ HSQC experiment of $\mathbf{O S}$ indicated three-bond correlations for the phosphorus signals, with ${ }^{1} \mathrm{H}$ signals as follows: $\mathrm{H} 1$ and $\mathrm{H} 2$ of residue $\mathbf{A}$ with ${ }^{31} \mathrm{P}$ signal at $\delta-2.1 \mathrm{ppm}, \mathrm{H} 4$ of $\mathrm{G}$ with ${ }^{31} \mathrm{P}$ signal at $\delta-0.2 \mathrm{ppm}$, and $\mathrm{H} 4$ of I with ${ }^{31} \mathrm{P}$ signal at $\delta 0.3 \mathrm{ppm}$, as shown in Figure 5. Therefore, based on these results and in agreement with other oligosaccharide structures from Shewanella species $[23,24]$, it was possible to hypothesize that the additional phosphoethanolamine is linked through a phosphoanhydride linkage to the phosphate group at position O-4 of the Kdo8N.

The sequence of the monosaccharides and the linkage positions were obtained from the ROESY and HMBC experiments. The latter spectrum, as illustrated in Figure 6, revealed the following inter-residue correlations: $\mathrm{H} 1$ of $\mathbf{G}$ with $\mathbf{C} 6$ of $\mathbf{A}, \mathrm{H} 1$ of $\mathbf{D}$ with $\mathbf{C} 5$ of $\mathrm{Kdo} 8 \mathrm{~N}$ (residue $\mathbf{I}$ ), $\mathrm{H} 1$ of $\mathbf{C}$ with $\mathbf{C} 6$ of $\mathbf{D}, \mathrm{H} 1$ of $\mathbf{E}$ with $\mathbf{C} 2$ of $\mathbf{D}, \mathrm{H} 1$ of $\mathbf{H}$ with $\mathbf{C} 7$ of $\mathbf{D}, \mathrm{H} 1$ of $\mathbf{F}$ with $\mathbf{C} 2$ of $\mathbf{C}$, and $\mathrm{H} 1$ of $\mathbf{B}$ with $\mathbf{C} 2$ of $\mathrm{H}$. The ROESY spectrum confirmed this sequence, since it revealed the following dipolar couplings: H1 of $\mathbf{D}$ with $\mathrm{H} 5$ of $\mathbf{I}, \mathrm{H} 1$ of $\mathbf{C}$ with $\mathrm{H} 6$ of $\mathbf{D}, \mathrm{H} 1$ of $\mathbf{H}$ with both H7s of $\mathbf{D}, \mathrm{H} 1$ of $\mathbf{E}$ with H2 of $\mathbf{D}, \mathrm{H} 1$ of $\mathbf{B}$ with $\mathrm{H} 2$ of $\mathbf{H}$, and $\mathbf{H} 1$ of $\mathbf{F}$ with $\mathrm{H} 2$ of $\mathbf{C}$. Moreover, the rotating frame Overhauser effect (ROE) contact between $\mathrm{H} 5$ of residue $\mathbf{D}$ and H3ax of I suggested a D configuration for Kdo8N [30]. Finally, ROE contacts between $\mathrm{H} 1$ of $\mathbf{G}$ and both $\mathrm{H} 6$ s of $\mathbf{A}$ were found.

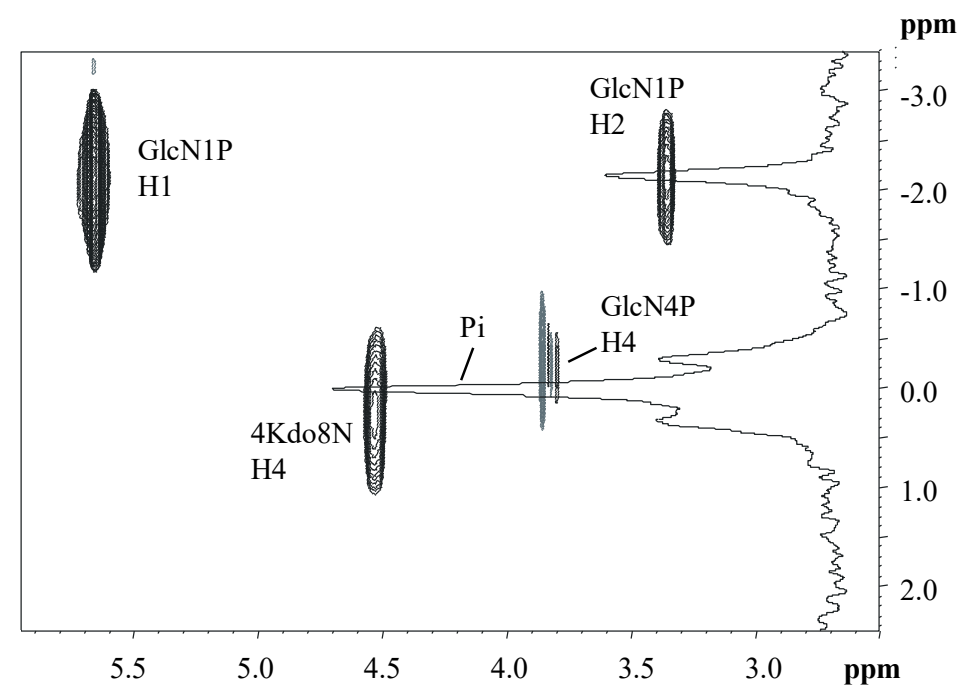

Figure 5. Expansion of the ${ }^{1} \mathrm{H}^{31} \mathrm{P}$ HSQC spectrum of the OS of the LOS from Shewanella sp. HM13. The spectrum was recorded in $\mathrm{D}_{2} \mathrm{O}$ at $298 \mathrm{~K}$ at $400 \mathrm{MHz}$.

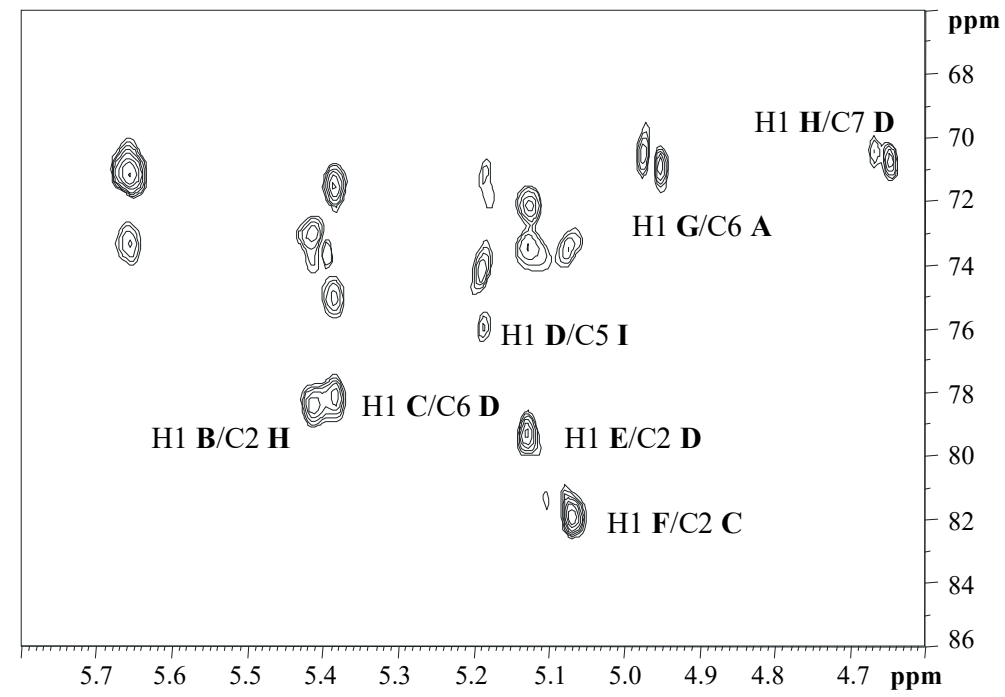

Figure 6. Anomeric region of the ${ }^{1} \mathrm{H},{ }^{13} \mathrm{C} \mathrm{HMBC}$ spectrum of the $\mathrm{OS}$ oligosaccharide. The spectrum was recorded in $\mathrm{D}_{2} \mathrm{O}$ at $298 \mathrm{~K}$ at $600 \mathrm{MHz}$. The letters refer to the residues as described in Table 1. 
All the reported data allowed us to determine the complete structure of the saccharidic backbone of the Shewanella sp. HM13 LOS, which is shown in Figure 7.

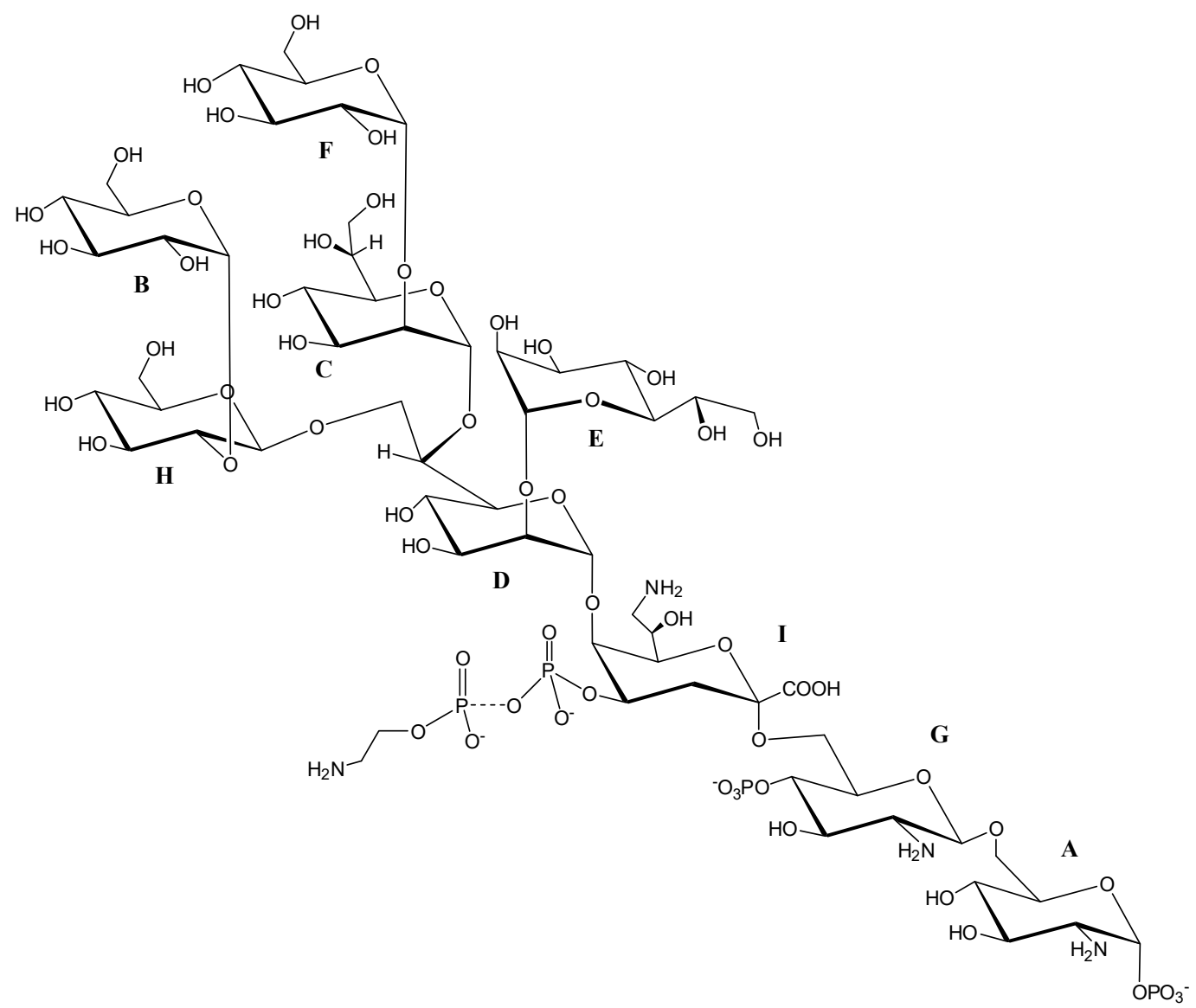

Figure 7. OS structure of the LOS from Shewanella sp. HM13.

\section{Materials and Methods}

\subsection{Bacteria Growth and LPS Isolation}

Shewanella sp. HM13, a psychrotrophic bacterium isolated from the intestine of horse mackerel (Trachurus japonicus), was cultured in $5 \mathrm{~mL}$ LB liquid medium overnight at $18^{\circ} \mathrm{C}$. Five milliliters of the culture were inoculated into $1 \mathrm{~L} \mathrm{LB}$ liquid medium, and the cells were grown at $4{ }^{\circ} \mathrm{C}$ until the $\mathrm{OD}_{600}$ reached 3.0-4.0. The cells were harvested at $6800 \times g, 4{ }^{\circ} \mathrm{C}$ for $10 \mathrm{~min}$. The cell pellets collected from $2 \mathrm{~L}$ cultures were freeze-dried. Dried bacterial cells $(1.4 \mathrm{~g})$ were extracted by the PCP method to give $34 \mathrm{mg}$ of LOS (yield $2.4 \% w / w$ of dried cells), and then by the hot phenol/water method as reported previously $[19,20]$.

\subsection{DOC-PAGE Analysis}

Polyacrylamide gel electrophoresis analysis (PAGE) was performed using the system of Laemmli [31] with sodium deoxycholate (DOC) as the detergent, as already described [32]. The gels were fixed in an aqueous solution of $40 \%$ ethanol and $5 \%$ acetic acid. The LOS extract bands were visualized by silver staining as previously described [33].

\subsection{Sugar and Fatty Acids Analysis}

The LOS sample $(0.5 \mathrm{mg})$ was subjected to a methanolysis reaction with $\mathrm{HCl} / \mathrm{CH}_{3} \mathrm{OH}(1.25 \mathrm{M}$, $1 \mathrm{~mL})$ at $80^{\circ} \mathrm{C}$ for $16 \mathrm{~h}$. The obtained monosaccharides were acetylated and analyzed as acetylated 
methyl glycosides by GC-MS. The analysis of the fatty acids, derivatized as methyl esters, was achieved as already reported [34].

The absolute configurations of the glucose and glucosamine were determined by gas chromatography of the acetylated (S)-2-octyl glycosides [35]. The heptose configurations were obtained through the alditol acetates GC-MS method. Briefly, a sample of the LOS $(0.5 \mathrm{mg})$, after a methanolysis reaction, was hydrolyzed at $120^{\circ} \mathrm{C}$ with $2 \mathrm{M}$ trifluoroacetic acid (TFA) for $2 \mathrm{~h}$, as already reported [36]. After neutralization, the sample was reduced with $\mathrm{NaBD}_{4}$ and finally acetylated and injected into the GC-MS. The configuration was obtained by comparison with authentic standards.

All the sample derivatives were analyzed on an Agilent Technologies gas chromatograph 6850A equipped with a mass selective detector $5973 \mathrm{~N}$ and a Zebron ZB-5 capillary column (Phenomenex, Bologna, Italy $30 \mathrm{~m} \times 0.25 \mathrm{~mm}$ i.d., flow rate $1 \mathrm{~mL} / \mathrm{min}, \mathrm{He}$ as carrier gas). Acetylated methyl glycosides were analyzed using the following temperature program: $140^{\circ} \mathrm{C}$ for $3 \mathrm{~min}$, then $140 \rightarrow 240^{\circ} \mathrm{C}$ at $3{ }^{\circ} \mathrm{C} / \mathrm{min}$. Analysis of acetylated octyl glycosides was performed as follows: $150{ }^{\circ} \mathrm{C}$ for $5 \mathrm{~min}$, then $150 \rightarrow 300{ }^{\circ} \mathrm{C}$ at $6{ }^{\circ} \mathrm{C} / \mathrm{min}$, and finally $300{ }^{\circ} \mathrm{C}$ for $5 \mathrm{~min}$. The temperature program for methyl esters of fatty acids was the following: $140{ }^{\circ} \mathrm{C}$ for $3 \mathrm{~min}$, then $140 \rightarrow 280^{\circ} \mathrm{C}$ at $10^{\circ} \mathrm{C} / \mathrm{min}$, and finally $280^{\circ} \mathrm{C}$ for $20 \mathrm{~min}$. The temperature program for alditol acetates was the following: $150{ }^{\circ} \mathrm{C}$ for $3 \mathrm{~min}$, and then $150 \rightarrow 330^{\circ} \mathrm{C}$ at $3^{\circ} \mathrm{C} / \mathrm{min}$.

\subsection{Deacylation of the LOS}

The LOS sample (30 mg) was dried over phosphorus anhydride in a vacuum chamber and then treated with hydrazine $(1.5 \mathrm{~mL})$ at $37^{\circ} \mathrm{C}$ for $2 \mathrm{~h}$. The precipitation of the LOS-OH was obtained by addition of cold acetone. The pellet was recovered after centrifugation $\left(4{ }^{\circ} \mathrm{C}, 7000 \mathrm{rpm}, 30 \mathrm{~min}\right)$, washed two times with cold acetone to remove the excess of hydrazine, suspended in water, and finally freeze-dried [37]. The LOS-OH $(8 \mathrm{mg})$ was submitted to a reaction with $\mathrm{KOH} 4 \mathrm{M}$ aq. $(1.0 \mathrm{~mL})$ for $16 \mathrm{~h}$ at $120{ }^{\circ} \mathrm{C}$. The crude reaction was neutralized with $\mathrm{HCl} 2 \mathrm{M}$ aq. (until pH 6) and extracted with $\mathrm{CHCl}_{3}$ for three times. The aqueous phase of the mixture was desalted on a Sephadex G-10 column (GE Healthcare, Pittsburgh, PA, USA, $2.5 \times 43 \mathrm{~cm}, 31 \mathrm{~mL} \mathrm{~h}^{-1}$, fraction volume $2.5 \mathrm{~mL}$, eluent $\mathrm{NH}_{4} \mathrm{HCO}_{3}$ $10 \mathrm{~mm}$ ). The eluted oligosaccharide fraction was freeze-dried $(1.5 \mathrm{mg})$.

\subsection{Methylation Analysis}

The linkage positions of the monosaccharides were obtained by the analysis of the partially methylated alditol acetates (PMAAs). The methylation reaction was achieved by incubating $1 \mathrm{mg}$ of the LOS sample with $\mathrm{CH}_{3} \mathrm{I}(100 \mu \mathrm{L})$ and $\mathrm{NaOH}$ powder in dimethyl sulfoxide (DMSO, $\left.300 \mu \mathrm{L}\right)$ for $20 \mathrm{~h}$ [38]. The mixture was analyzed by GC-MS with the following temperature program: $90^{\circ} \mathrm{C}$ for $1 \mathrm{~min}$, then $90 \rightarrow 140{ }^{\circ} \mathrm{C}$ at $25^{\circ} \mathrm{C} / \mathrm{min}$, then $140 \rightarrow 200{ }^{\circ} \mathrm{C}$ at $5^{\circ} \mathrm{C} / \mathrm{min}$, then $200 \rightarrow 280^{\circ} \mathrm{C}$ at $10{ }^{\circ} \mathrm{C} / \mathrm{min}$, and finally $280^{\circ} \mathrm{C}$ for $10 \mathrm{~min}$.

\subsection{Mass Spectrometry Analysis}

MALDI-TOF mass spectra were acquired on a ABSCIEX TOF/TOF ${ }^{\mathrm{TM}} 5800$ (AB SCIEX, Darmstadt, Germany) mass spectrometer equipped with an Nd:YLF laser with a $\lambda$ of $345 \mathrm{~nm}$, a $<500$-ps pulse length, and a repetition rate of up to $1000 \mathrm{~Hz}$. Approximately 2000 laser shots were accumulated for each spectrum. The calibration of the mass spectra was obtained with a hyaluronan oligosaccharides mixture. A solution of 2,5-dihydroxybenzoic acid (DHB) in $20 \% \mathrm{CH}_{3} \mathrm{CN}$ in water $\left(25 \mathrm{mg} \mathrm{mL}^{-1}\right)$ was used as the matrix. The samples were desalted on a Dowex 50WX8 $\left(\mathrm{H}^{+}\right.$form $)$and dissolved in 2-propanol/water with a 1:1 ratio. The spectra were calibrated and processed under computer control by using the Data Explorer software (v0.2.0).

\subsection{NMR Spectroscopy}

1D and 2D NMR spectra were obtained using a Bruker Avance $600 \mathrm{MHz}$ spectrometer (Billerica, MA, USA) equipped with a cryoprobe. All the NMR experiments (COSY, TOCSY, ROESY, DEPT-HSQC, 
and $\mathrm{HMBC}$ ) were performed using standard pulse sequences available in the Bruker software (version 2.1) [39]. NMR spectra were recorded at $298 \mathrm{~K}$, and the mixing time for the TOCSY and ROESY experiments was $100 \mathrm{~ms}$. All the experiments were performed by using sodium 3-trimethylsilyl- $\left(2,2,3,3-{ }^{2} \mathrm{H}_{4}\right)$-propanoate (TSP, $\left.\delta_{\mathrm{H}} 0.00\right)$ and 1,4-dioxane in $\mathrm{D}_{2} \mathrm{O}\left(\delta_{\mathrm{C}} 67.40\right)$ as external references. ${ }^{31} \mathrm{P}$ and ${ }^{1} \mathrm{H}-{ }^{31} \mathrm{P}$ spectra were recorded at $298 \mathrm{~K}$ using a Bruker Ascend $400 \mathrm{MHz}$ spectrometer (Billerica, MA, USA).

\section{Conclusions}

In this paper, the complete structure of the sugar backbone of the LOS from the cold-adapted Shewanella sp. HM13 is reported. The structure has been obtained by chemical analysis, NMR spectroscopy, and MALDI-TOF mass spectrometry.

The oligosaccharide shares some structural features with those isolated from other Shewanella strains. The presence of the Kdo8N is confirmed as a hallmark of Shewanella species, having been already reported for the species oneidensis [23], algae [27], putrefaciens [40], pacifica [24], and Shewanella spp. MR-4 [21]. In addition, the D,D-configured heptose holds a central position in the oligosaccharide structure, as well as for all the other characterized LOS structures [21,23,24,27,40].

The rough nature of the Shewanella sp. HM13 LPS is not surprising, since this has also been reported for other Shewanella species [21,23,24,27,40]. Nevertheless, it is worth noting that this feature is common among the LPSs isolated from cold-adapted Gram-negative bacteria [41-45]. A possible explanation lies in the enhanced flexibility and stability of the outer membrane when the O-polysaccharide chain is absent [46].

Finally, to shed light on the possible structural differences among OM components of both bacterial cells and OMVs, it will be very interesting to characterize the LPS isolated from Shewanella sp. HM13 OMVs.

Author Contributions: A.C. and R.D.G. performed chemical analysis and NMR spectra; C.C. and K.K. prepared bacterial cells; A.C. and M.M.C. contributed for mass spectra interpretation; A.C., S.C., and M.M.C. contributed for NMR data interpretation; J.K., T.K., and M.M.C. conceived and designed the experiments; A.C. and M.M.C. wrote the paper.

Funding: This research was financially supported in part by JSPS KAKENHI (18K19178 to T.K. and 16K14885 to J.K.).

Conflicts of Interest: The authors declare no conflict of interest.

\section{References}

1. Feller, G.; Gerday, C. Psychrophilic enzymes: Hot topics in cold adaptation. Nat. Rev. Microbiol. 2003, 1, 200-208. [CrossRef]

2. Casillo, A.; Papa, R.; Ricciardelli, A.; Sannino, F.; Ziaco, M.; Tilotta, M.; Selan, L.; Marino, G.; Corsaro, M.M.; Tutino, M.L.; et al. Anti-biofilm activity of a long-chain fatty aldehyde from Antarctic Pseudoalteromonas haloplanktis TAC125 against Staphylococcus epidermidis biofilm. Front. Cell. Infect. Microbiol. 2017, 7, 1-13. [CrossRef] [PubMed]

3. Perfumo, A.; Banat, I.M.; Marchant, R. Going Green and Cold: Biosurfactants from low-temperature environments to biotechnology applications. Trends Biotechnol. 2018, 36, 277-287. [CrossRef] [PubMed]

4. Feller, G. Protein stability and enzyme activity at extreme biological temperatures. J. Phys. Condens. Matter 2010, 22, 323101-323117. [CrossRef] [PubMed]

5. Bar Dolev, M.; Braslavsky, I.; Davies, P.L. Ice-Binding proteins and their function. Annu. Rev. Biochem. 2016, 85, 515-542. [CrossRef] [PubMed]

6. Carillo, S.; Casillo, A.; Pieretti, G.; Parrilli, E.; Sannino, F.; Bayer-Giraldi, M.; Cosconati, S.; Novellino, E.; Ewert, M.; Deming, J.W.; et al. A unique capsular polysaccharide structure from the psychrophilic marine bacterium Colwelliapsychrerythraea $34 \mathrm{H}$ that mimicks antifreeze (glyco) proteins. J. Am. Chem. Soc. 2015, 137, 179-189. [CrossRef] [PubMed] 
7. Casillo, A.; Parrilli, E.; Sannino, F.; Mitchell, D.E.; Gibson, M.I.; Marino, G.; Lanzetta, R.; Parrilli, M.; Cosconati, S.; Novellino, E.; et al. Structure-activity relationship of the exopolysaccharide from a psychrophilic bacterium: A strategy for cryoprotection. Carbohydr. Polym. 2017, 156, 364-371. [CrossRef] [PubMed]

8. Frias, A.; Manresa, A.; de Oliveira, E.; López-Iglesias, C.; Mercade, E. Membrane Vesicles: A common feature in the extracellular matter of cold-adapted Antarctic Bacteria. Microb. Ecol. 2010, 59, 476-486. [CrossRef]

9. Nevot, M.; Deroncelé, V.; Messner, P.; Guinea, J.; Mercadé, E. Characterization of outer membrane vesicles released by the psychrotolerant bacterium Pseudoalteromonas antarctica NF3. Environ. Microbiol. 2006, 8, 1523-1533. [CrossRef]

10. Pérez-Cruz, C.; Mercadé, E. Outer Membrane Vesicles From Cold-Adapted Antarctic Bacteria; Recent Advances in Pharmaceutical Sciences IV; Muñoz-Torrero, D., Vázquez-Carrera, M., Estelrich, J., Eds.; Research Signpost: Kerala, India, 2014; pp. 55-72. ISBN 978-81-308-0554-2.

11. Schwechheimer, C.; Kuehn, M.J. Outer-membrane vesicles from Gram-negative bacteria: Biogenesis and functions. Nat. Rev. Microbiol. 2015, 13, 605-619. [CrossRef]

12. Deatheragea, B.L.; Cooksona, B.T. Membrane vesicle release in Bacteria, Eukaryotes, and Archaea: A conserved yet underappreciated aspect of microbial life. Infect. Immun. 2012, 80, 1948-1957. [CrossRef] [PubMed]

13. Caroff, M.; Karibian, D. Structure of bacterial lipopolysaccharides. Carbohydr. Res. 2003, 338, $2431-2447$. [CrossRef] [PubMed]

14. Carillo, S.; Pieretti, G.; Bedini, E.; Parrilli, M.; Lanzetta, R.; Corsaro, M.M. Structural investigation of the antagonist LPS from the cyanobacterium Oscillatoria planktothrix FP1. Carbohydr. Res. 2014, 388, 73-80. [CrossRef] [PubMed]

15. Westphal, O.; Luderitz, O.; Galanos, C.; Mayer, H.; Rietschel, E.T. Advances in Immunopharmacology; Chedid, L., Hadden, J.W., Spreafico, F., Eds.; Pergamon Press: Oxford, UK, 1986; pp. 13-34.

16. Wilkinson, S.C. Surface Carbohydrates of the Procaryotic Cell; Sutherland, I.W., Ed.; Academic Press Inc.: New York, NY, USA, 1977; pp. 97-105.

17. Alexander, C.; Rietschel, E.T. Bacterial lipopolysaccharides and innate immunity. J. Endoxin Res. 2001, 7, 167-202. [CrossRef]

18. Chen, C.; Kawamoto, J.; Kawai, S.; Tame, A.; Kato, C.; Imai, T.; Kurihara, T. Isolation of a novel bacterial strain capable of producing abundant extracellular membrane vesicles carrying a single major cargo protein and analysis of its transport mechanism. Appl. Environ. Microbiol.. under review.

19. Galanos, C.; Lüderitz, O.; Westphal, O. New Method for the extraction of R Lipopolysaccharides. Eur. J. Biochem. 1969, 9, 245-249. [CrossRef] [PubMed]

20. Westphal, O.; Jann, K. Bacterial lipopolysaccharides extraction with phenol-water and further applications of the procedure. Methods Carbohydr. Chem. 1965, 5, 83-91.

21. Vinogradov, E.; Kubler-Kielb, J.; Korenevsky, A. The structure of the carbohydrate backbone of the LPS from Shewanella spp. MR-4. Carbohydr. Res. 2008, 343, 2701-2705. [CrossRef]

22. Vinogradov, E.; Korenevsky, A.; Beveridge, T.J. The structure of the carbohydrate backbone of the LPS from Shewanella putrefaciens CN32. Carbohydr. Res. 2002, 337, 1285-1289. [CrossRef]

23. Vinogradov, E.; Korenevsky, A.; Beveridge, T.J. The structure of the rough-type lipopolysaccharide from Shewanella oneidensis MR-1, containing 8-amino-8-deoxy-Kdo and an open-chain form of 2-acetamido-2-deoxy-D-galactose. Carbohydr. Res. 2003, 338, 1991-1997. [CrossRef]

24. Silipo, A.; Leone, S.; Molinaro, A.; Sturiale, L.; Garozzo, D.; Nazarenko, E.L.; Gorshkova, R.P.; Ivanova, E.P.; Lanzetta, R.; Parrilli, M. Complete structural elucidation of a novel lipooligosaccharide from the outer membrane of the marine bacterium Shewanella pacifica. Eur. J. Org. Chem. 2005, 11, 2281-2291. [CrossRef]

25. Gibson, B.W.; Engstrom, J.J.; Hines, C.M.W.; Falick, A.M. Characterization of bacterial lipooligosaccharides by delayed extraction matrix-assisted laser desorption ionization time-of-flight mass spectrometry. J. Am. Soc. Mass. Spectrom. 1997, 8, 645-658. [CrossRef]

26. Pieretti, G.; Carillo, S.; Lindner, B.; Kim, K.K.; Lee, K.C.; Lee, J.S.; Lanzetta, R.; Parrilli, M.; Corsaro, M.M. Characterization of the core oligosaccharide and the O-antigen biological repeating unit from Halomonasstevensii LPS: The first case of O-antigen linked to the inner core. Chem. Eur. J. 2012, 18, 3729-3735. [CrossRef] [PubMed] 
27. Vinogradov, E.; Korenevsky, A.; Beveridge, T.J. The structure of the core region of the lipopolysaccharide from Shewanella algae BrY, containing 8-amino-3,8-dideoxy-D-mannooct-2-ulosonic acid. Carbohydr. Res. 2004, 339, 737-740. [CrossRef] [PubMed]

28. Lipkind, G.M.; Shashkov, A.S.; Knirel, Y.A.; Vinogradov, E.V.; Kochetkov, N.K. A computer-assisted structural analysis of regular polysaccharides on the basis of ${ }^{13} \mathrm{C}-\mathrm{NMR}$ data. Carbohydr. Res. 1988, 175, 59-75. [CrossRef]

29. Birnbaum, G.I.; Roy, R.; Brisson, J.R.; Jennings, H.J.J. Conformations of ammonium 3-deoxy-D-manno-2-octulosonate (KDO) and methyl $\alpha$-and $\beta$-ketopyranosides of KDO: X-ray structure and 1H NMR analyses. Carbohydr. Chem. 1987, 6, 17-39. [CrossRef]

30. Bock, K.; Vinogradov, E.V.; Holst, O.; Brade, H. Isolation and structural analysis of oligosaccharide phosphates containing the complete carbohydrate chain of the lipopolysaccharide from Vibrio cholerae Strain H11 (Non-O1). Eur. J. Biochem. 1994, 225, 1029-1039. [CrossRef]

31. Laemmli, U.K. Most commonly used discontinuous buffer system for SDS electrophoresis. Nature 1970, 227, 680-685. [CrossRef]

32. Casillo, A.; Ståhle, J.; Parrilli, E.; Sannino, F.; Mitchell, D.E.; Pieretti, G.; Gibson, M.I.; Marino, G.; Lanzetta, R.; Parrilli, M.; et al. Structural characterization of an all-aminosugar-containing capsular polysaccharide from Colwellia psychrerythraea 34H. Antonie Leeuwenhoek 2017, 110, 1377-1387. [CrossRef]

33. Tsai, C.M.; Frasch, C.E. A sensitive silver stain for detecting lipopolysaccharides in polyacrylamide gels. Anal. Biochem. 1982, 119, 115-119. [CrossRef]

34. Casillo, A.; Ziaco, M.; Lindner, B.; Parrilli, E.; Schwudke, D.; Holgado, A.; Verstrepen, L.; Sannino, F.; Beyaert, R.; Lanzetta, R.; et al. Unusual lipid A from a cold-adapted bacterium: Detailed structural characterization. ChemBioChem 2017, 18, 1845-1854. [CrossRef] [PubMed]

35. Leontein, K.; Lindberg, B.; LoÈnngren, J. Assignment of absolute configuration of sugars by g.l.c. of their acetylated glycosides from chiral alcohols. Carbohydr. Res. 1978, 62, 359-362. [CrossRef]

36. Pieretti, G.; Corsaro, M.M.; Lanzetta, R.; Parrilli, M.; Canals, R.; Merino, S.; Tomás, J.M. Structural studies of the O'glycosides from chiral alco Plesiomonas shigelloides Strain 302-73 (Serotype O1). Eur. J. Org. Chem. 2008, 18, 3149-3155. [CrossRef]

37. Holst, O. De-acylation of lipopolysaccharides and isolation of oligosaccharide phosphates. In Bacterial Toxins: Methods and Protocols; Methods in Molecular Biology; Holst, O., Ed.; Humana Press: Totowa, NJ, USA, 2000; Volume 145, pp. 345-353.

38. Ciucanu, I.; Kerek, F. A simple and rapid method for the permethylation of carbohydrates. Carbohydr. Res. 1984, 131, 209-217. [CrossRef]

39. De Castro, C.; Lanzetta, R.; Leone, S.; Parrilli, M.; Molinaro, A. The structural elucidation of the Salmonella enterica subsp. enterica, reveals that it contains both O-factors 4 and 5 on the LPS antigen. Carbohydr. Res. 2013, 370, 9-12. [CrossRef]

40. Moule, A.L.; Galbraith, L.; Cox, A.D.; Wilkinson, S.G. Characterisation of a tetrasaccharide released on mild acid hydrolysis of LPS from two rough strains of Shewanella species representing different DNA homology groups. Carbohydr. Res. 2004, 339, 1185-1188. [CrossRef] [PubMed]

41. Corsaro, M.M.; Lanzetta, R.; Parrilli, E.; Parrilli, M.; Tutino, M.L. Structural investigation on the lipooligosaccharide fraction of psychrophilic Pseudoalteromonas haloplanktis TAC 125 bacterium. Eur. J. Biochem. 2001, 268, 5092-5097. [CrossRef]

42. Corsaro, M.M.; Pieretti, G.; Lindner, B.; Lanzetta, R.; Parrilli, E.; Tutino, M.L.; Parrilli, M. Highly phosphorylated core oligosaccharide structures from cold-adapted Psychromon asarctica. Chem. Eur. J. 2008, 14, 9368-9937. [CrossRef]

43. Carillo, S.; Pieretti, G.; Parrilli, E.; Tutino, M.L.; Gemma, S.; Molteni, M.; Lanzetta, R.; Parrilli, M.; Corsaro, M.M. Structural investigation and biological activity of the lipooligosaccharide from the psychrophilic bacterium Pseudoalteromonas haloplanktis TAB 23. Chem. Eur. J. 2011, 17, 7053-7060. [CrossRef]

44. Carillo, S.; Pieretti, G.; Lindner, B.; Parrilli, E.; Sannino, F.; Tutino, M.L.; Lanzetta, R.; Parrilli, M.; Corsaro, M.M. Structural Characterization of the core oligosaccharide isolated from the Lipopolysaccharide of the psychrophilic bacterium Colwellia psychrerythraea Strain 34H. Eur. J. Org. Chem. 2013, 3771-3779. [CrossRef] 
45. Casillo, A.; Parrilli, E.; Sannino, F.; Lindner, B.; Lanzetta, R.; Parrilli, M.; Tutino, M.L.; Corsaro, M.M. Structural investigation of the oligosaccharide portion isolated from the lipooligosaccharide of the permafrost psychrophile Psychrobacter arcticus 273-4. Mar. Drugs 2015, 13, 4539-4555. [CrossRef] [PubMed]

46. Corsaro, M.M.; Casillo, A.; Parrilli, E.; Tutino, M.L. Molecular structure of lipopolysaccharides of cold-adapted bacteria. In Psychrophiles: From Biodiversity to Biotechnology; Margesin, R., Ed.; Springer International Publishing AG: Cham, Switzerland, 2017; Chapter 13; pp. 285-303. 